\title{
Rock Settlements in Central Sicily (Italy) Between Late Antiquity and Middle Ages
}

\section{Daniela Patti*}

Associate professor of Christian and Medieval archaeology, university of Enna, Italy

Submission: March15, 2018; Published: July 02, 2018

*Corresponding author: Daniela Patti, Associate professor of Christian and Medieval archaeology, university of Enna, Kore, Italy, Email: daniela. patti@unikore.it

\begin{abstract}
The rupestrian habitat is a distinctive element of the Mediterranean landscape. It is more a dwelling culture which has been shared by different civilizations; a global phenomenon should be investigated in all of its aspects. The Northern area of central Sicily (Italy) has considerable archaeological potential, mainly linked to the impressive rocky habitat scenery.A great connection is evident between the settlements in Late Antiquity, mainly linked to the burial caves and the network of roads connected to the main traffic routes known by the ancient sources, later to be linked to the Italian-Greek monasteries. Many of them are located just on the Nebrodi Mountains, where - it's no coincidence - the Byzantine army reorganizes himself against the Islamic advance.
\end{abstract}

Keywords: Central Sicily; Rupestrian habitat; Ancient viability; Landscape; Mediterranean area; Tyrrhenian Coast; Population; Roman age; Poleographic; Island; Mountains; History; Rocky ridges; Classical age

\section{Introduction}

Sicily is located in the south of Italy, in the central Mediterranean area (Figure 1). The history of Isle, is the result of a long and a complex process that has been going on for quite a while; a place of ancient and several relationships, which has made it the centre of attraction of the population, defining an ancient landscape that was to be very different from the actual

image with few towns, especially located on the coast of the isle. The area of central Sicily is the natural geographical center of the Island; it is crossed by a connected road network between Eastern Sicily and the Tyrrhenian Coast, and the inland areas that in the Roman Age were constituted by the important highway Via Valeria, mentioned in the Itinerarium Antonini[1] (Figure 2).

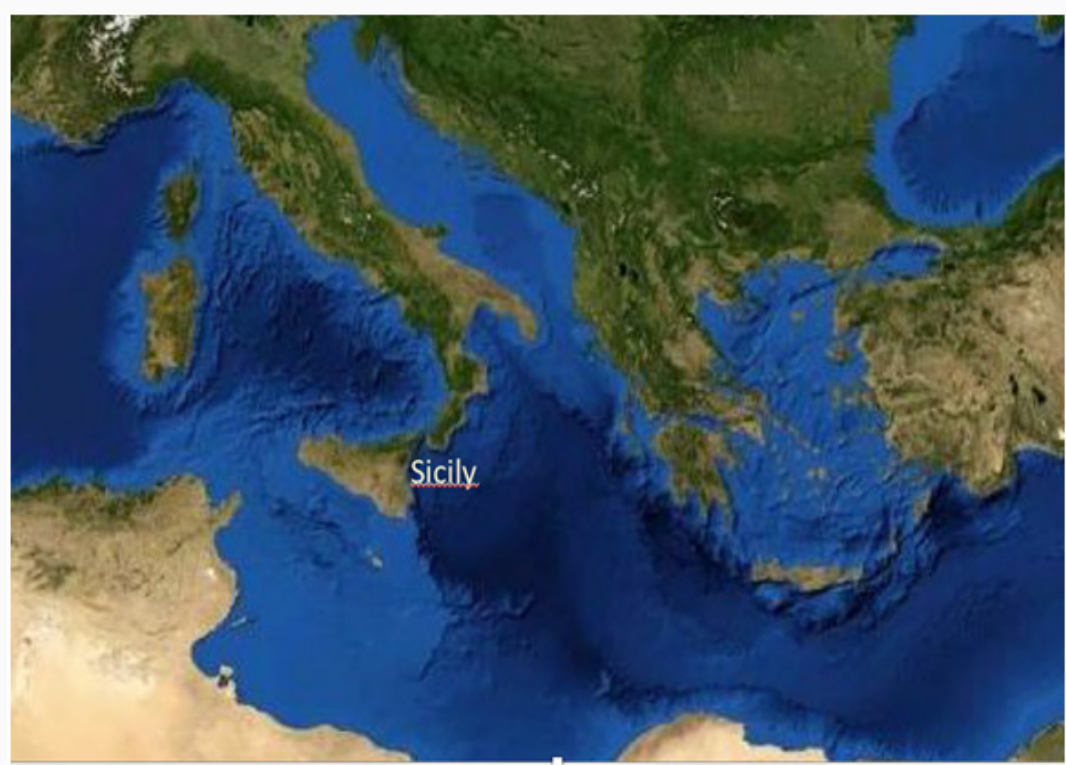

Figure 1: The Sicily in the Mediterranean area. 


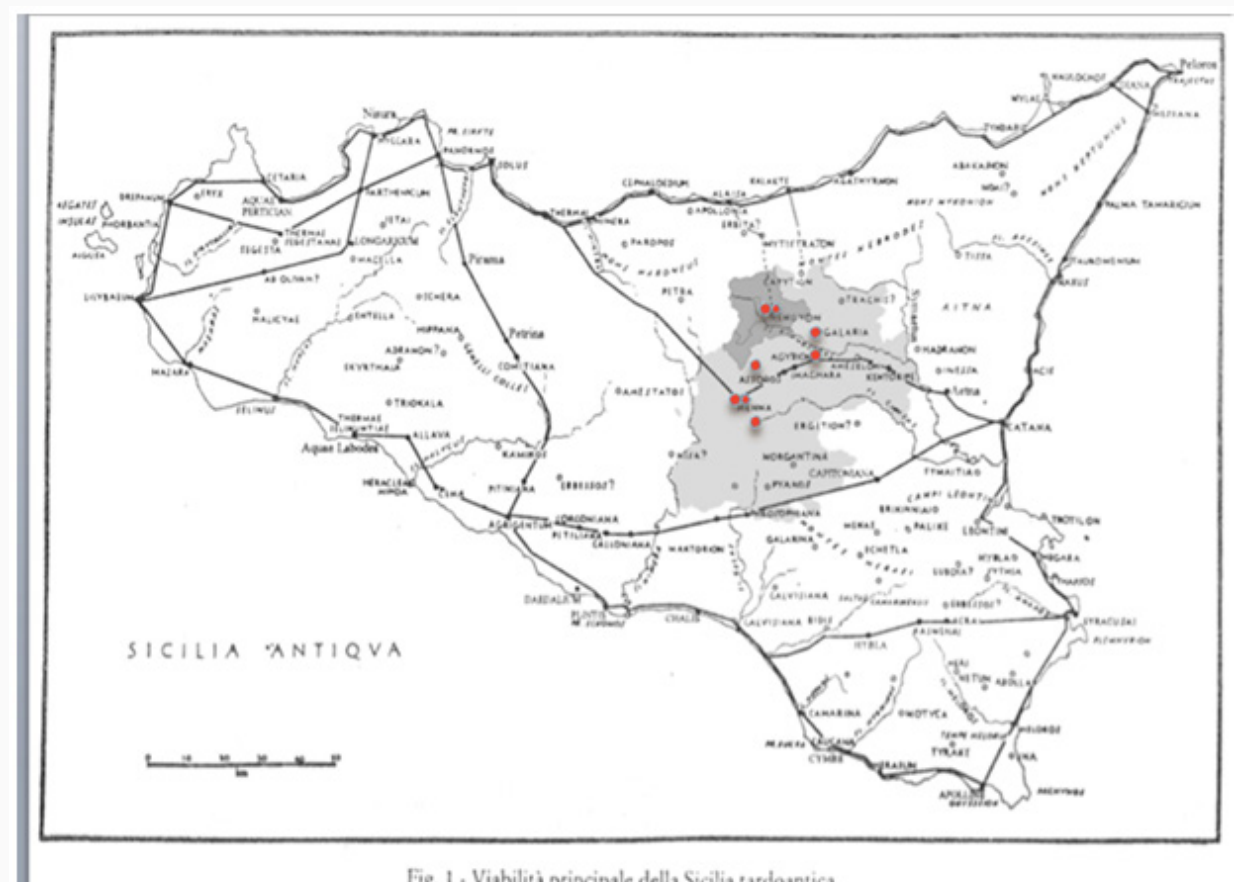

Fig. 1. Viabilita principale della Sicilia tardoantica.

Figure 2: The viability systsem in ancient Sicily. The central area of Island.

Since ancient times, the presence of different geomorphologic characteristics and environmental factors, has obviously influenced the poleographic distribution and the types of settlements, which takes on deep diversified aspects in the south and north of the current Province (Enna), the result of a choice that depended on the divisions of modern administration, not coinciding, in any way, with a precise entity of the Ancient Age.Unlike what is known in the scientific literature, in this very neglected area of research, which in the past has given priority to Sicily's coastline and the monumental evidence of the classical age, but instead, is characterized by a long history of human settlement that in different centuries had involved its neighborhoods.Even more serious, is the gap in the Northern area of the province, involving the re-collapsed territories in the ancient Val Demone, and characterized by a habitat which is typically rocky.Unknown are the real sizes and chronological terms.

The rocky habitat in the central area of the Island, partially know by ancient travelers [2] and historians[3], is still visible today in some parts of the Nebrodi Mountains (Figure 3). However, a systematic and comprehensive survey of the sites is missing; most of which are unknown, that up until now, the possibilities of a typological and chronological setting of the occurrences in the central Sicily were precluded, otherwise noted in Central and Southern Italy and in the Mediterranean area.

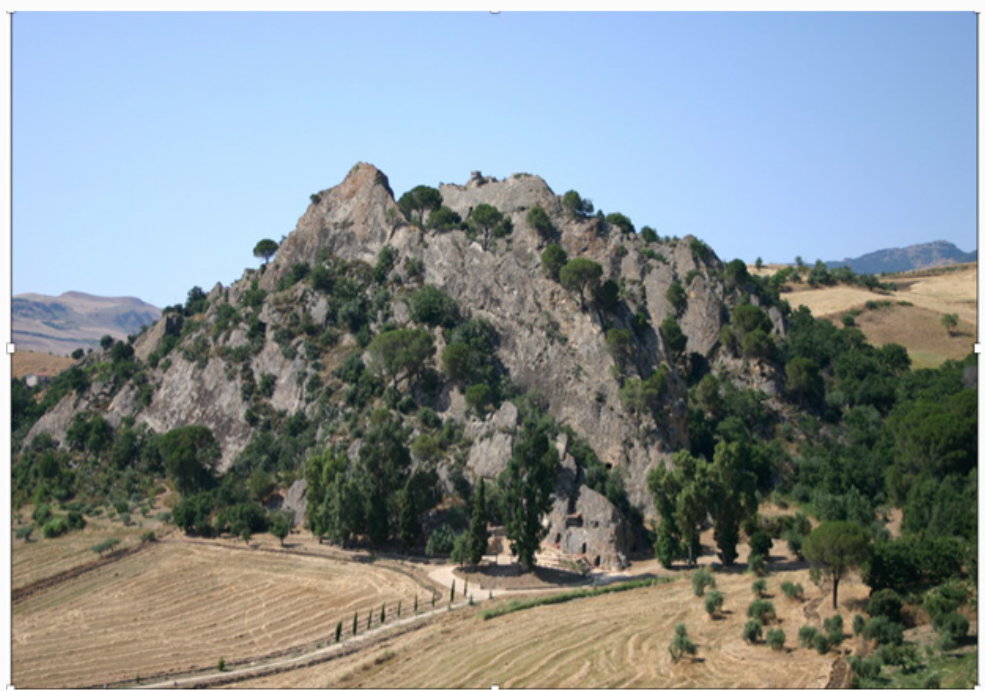

Figure 3: The rock landscape in the Northern of central Sicily.The settlement of "Balzodella Rossa". 
The use of the rocky units, characterized by stratifications, due to the continuous and prolonged use in time, and the transformations consequent to the changes: funeral, cultic, housing or productive, have obliterated, in most cases, the testimonies related to the most ancient phases and make it very difficult to clarify the origin and the evolution of the formation of the "settlement landscape" in Late Antiquity [4].Thanks to the systematic archaeological surveys carried out in the territory of Nicosia and Sperlinga have been uncovered several settlement burials of Late Antique Age [5], located in closely topographic proximity with the viability system towards the Nebrodi Mountain, where the Byzantine Empire organized the last defence against the Islamic advance in Sicily. The strategic importance of this area will be further confirmed later when it became the military stronghold of the Norman Conquest and of the reorganization of the Christian church promoted on Sicily from the Great Count Roger.

Despite the problems of research related to the exploration of the territory and the difficulty of establishing an absolute chronology; in the absence of systematic archaeological investigations and sources, the rocky habitat - the settlement phenomenon that lasts a lifetime not inferior to the urban model-it is increasingly getting to be an essential component of the process of rural settlement common in many areas of the Mediterranean, often gives us back the strong connection of thesettlement in Antiquity, characterized by the continued use of the rock unit with different functional purposes in the various times [6]. The setting of the settlement dynamics of this area of inland Sicily, is closely linked to the rocky habitat, which strictly speaking, must be considered the archaeological heritage of Enna landscape, historically 'layered', affected by continuing settlements, long a wide chronological span that from prehistory, even in its various links and transformations, reaches to nowadays.

The reinterpretation of the rock habitat has produced as an important result, the beginning of cataloging its own elements of the environment, such as road networks, the rural landscape, toponomy, also through the re-interpretation of the sources. In particular, the viability of the territory, presents itself as researches primary objective for the importance that it seems to have played in the dynamics of the population.The road routes have influenced the life and development of the settlements, or were the logical consequence, especially in the Middle Ages. Reorganization of the dromos in the Byzantine Age, along the rocky areas of the Nebrodi Mountains [7], permitted to link the continuity of life in the Late Antiquity settlements along the two inland roads to Gangi that constitutes one of the important road axes heading towards Messina.The narrow interconnection between viability and distribution of the settlements clearly emerges for this territory, documented for the late Roman and Late Antique Age by the numerous burials with arcosolium tombs (Figure 4), dug at the top of the rocky ridges, which draw, despite the simple of the excavation documented in most of the cases, the types of catacombs present in the Syracuse area [8].

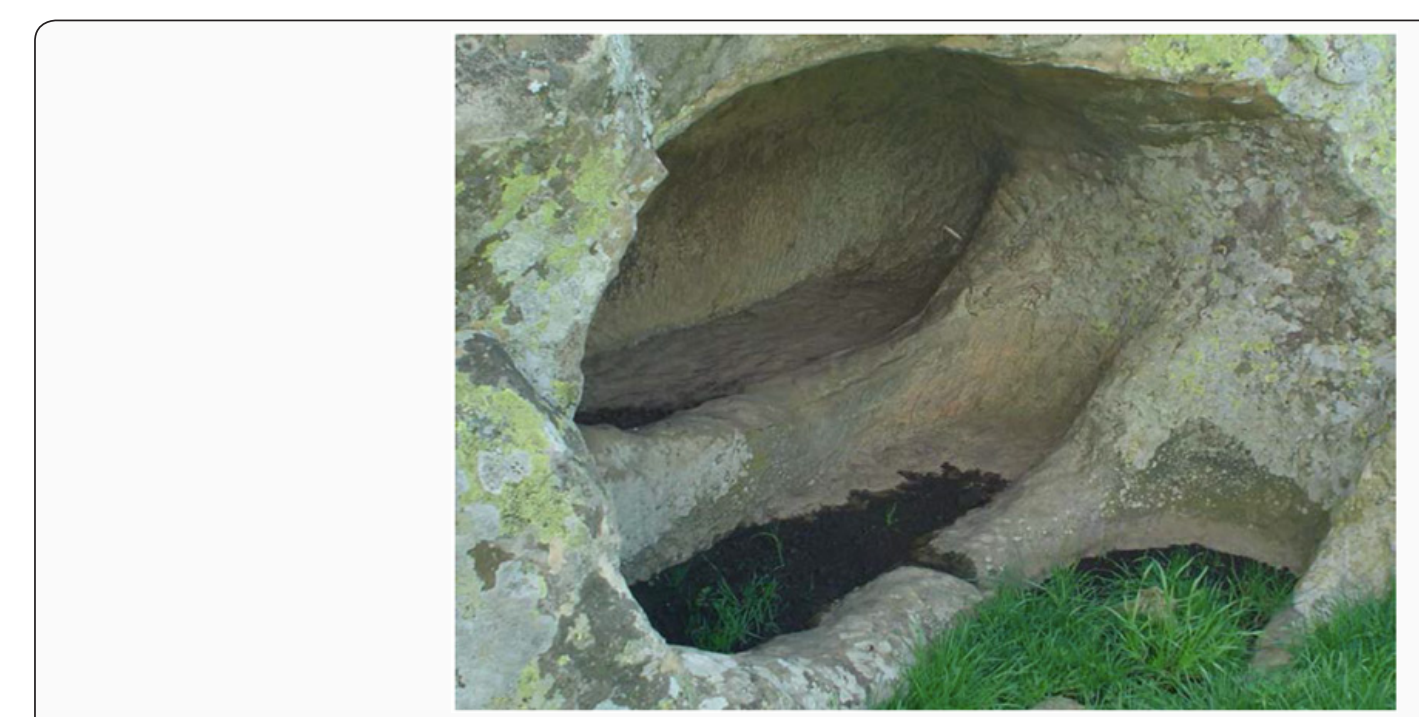

Figure 4: The rock burials in the Northern of central Sicily in the Late Antiquity. The arcosolium tombs of "Rocca Cuba".

The location of the burials spaces and of the related settlements must be, therefore, brought into relation with the organization of the roads of the territory, and, in particular, with the ancient roads, many of which reused and espanded in the $18^{\text {th }}$ century (called in the sources "regie trazzere") [9], still in use today that from Nicosia lead respectively to the centers of Agira and to Sperlinga and Gangi, through the neighborhoods of Casalini and Vaccarra (proposal for identifying Imachara, ancient city know by the sources), along the river Sperlinga.In fact, the development of the road network, seems to adapt to the route of the river, along the important axis of major transit, connecting North-South, documented in this territory from Roman times until the XIIthcentury [10], used by small rural communities that in Late Antiquity, they take advantage of therocky ridges to dig their own burials. 


\section{References}

1. Uggeri G (2004) La viabilità della Sicilia in età romana. Galatina, Italy, pp. 115 .

2. Houel J (1977) Voyage pittoresque des isles de Sicile, de Malte et de Lipari. In: Macchia G, Sciascia L, Vallet G (a cura di), Viaggio in Sicilia e a Malta, Palermo \& Napoli, p. 37.

3. Amico V (1856) Dizionario topografico della Sicilia, tradotto ed annotato da Gioacchino Di Marzo, Palermo. Italy.

4. Messina A, Le Chiese rupestri del Val Demone e del Val di Mazara, ISBI, Palermo p. 14.

5. Patti D (2007) Il territorio di Nicosia e Sperlinga. Primi dati per una carta archeologica, Enna, Italy.

6. Maurici F (1986) Castelli medievali in Sicilia. Dai bi ‘zantini ai normanni, Palermo p. 32; Sul popolamento epigeo e ipogeo della Sicilia nei secoli XIII e XIV. In: Fonseca CD (Eds.), La Sicilia rupestre ne contesto delle civiltà mediterranee, Atti del VI convegno internazionale di studio sulla civiltà rupestre mediterranea nel mezzogiorno d'Italia, Catania- Pantalica-Ispica, 7-12 settembre 1981, Galatina, pp. 319-340.

7. Arcifa L (1997) Vie di comunicazione e potere in Sicilia (secoli XI-XIII). Insediamenti monastici e controllo del territorio. In: GELICHI S (Eds.), Atti del I Congresso Nazionale di Archeologia Medievale, Pisa, 29-31 maggio, Firenze, Italy, pp. 181-186.

8. Agnello SL, Marchese AM, La necropoli tardo romana. In: Polacco L (Eds.), Il Teatro antico di Siracusa, pars altera, Rimini, p. 59-78.

9. Arcifa L (1995) Viabilità e politica stradale in Sicilia". In: Di Stefano Cadei (Eds.), Federico e la Sicilia. Dalla terra alla corona, I, Archeologia e Architettura, Palermo, Italy, p. 27-33.

10. Bejor G (2004) Tucidide 7,32 e le Vie $\Delta \mathrm{IA} \Sigma \mathrm{IKE} \Lambda \Omega \mathrm{N}$ nel settentrione della Sicilia in 'Annali della Scuola Normale Superiore di Pisa', Classe di Lettere e Filosofia, Serie III, pp. 756.

\section{Your next submission with Juniper Publishers will reach you the below assets}

- Quality Editorial service

- Swift Peer Review

- Reprints availability

- E-prints Service

- Manuscript Podcast for convenient understanding

- Global attainment for your research

- Manuscript accessibility in different formats

( Pdf, E-pub, Full Text, Audio)

- Unceasing customer service

Track the below URL for one-step submission https://juniperpublishers.com/online-submission.php 